\title{
Evaluating Streetscape Modifications in Los Angeles, California with a Health Lens
}

\author{
Gabrielle Green ${ }^{1}$, Lauren N. Gase ${ }^{1}$, Chandini Singh ${ }^{1}$, and Tony Kuo ${ }^{1,2,3,4}$ \\ ${ }^{1}$ Division of Chronic Disease and Injury Prevention, \\ Los Angeles County Department of Public Health \\ ${ }^{2}$ Department of Family Medicine, David Geffen School of Medicine at UCLA \\ ${ }^{3}$ Department of Epidemiology, UCLA Fielding School of Public Health \\ ${ }^{4}$ Population Health Program, UCLA Clinical and Translational Science Institute
}

\begin{abstract}
Background and Purpose: Despite growing evidence linking health and the built environment, local health departments are often not involved in the evaluation of a streetscape modification project. This paper describes an assessment conducted by a local health department to address this gap by using a health lens to evaluate the installation of painted curb extensions on a commercial corridor in Los Angeles. Methods: The local health department conducted an observational pre-post study of pedestrian and motorist data at both an intersection receiving the painted curb extension and a comparison intersection along the same corridor that had already received the extension. The study also analyzed streetscape features along the corridor related to walkability, to understand the painted curb extension in the context of the broader built environment. Results: The painted curb extension did not appear to significantly impact pedestrian and motorist behavior, though some slight changes were observed. Pedestrians along the corridor generally exhibited safe behavior at intersections, but encountered dangerous driver behavior and built environment barriers, which can discourage walking. Conclusion: This case study demonstrates how health considerations can be integrated into an evaluation of a streetscape modification project, and can provide guidance for other health practitioners developing such evaluation projects in their own jurisdictions.
\end{abstract}

(C) 2019 Californian Journal of Health Promotion. All rights reserved.

Keywords: Built environment, physical activity, walking, pedestrian, health department

\section{Introduction}

Evidence suggests that modifying the built environment to promote pedestrian activity changing the physical aspects of a neighborhood, such as buildings and streetscape features - can help increase physical activity levels and, in turn, prevent or reduce overweight and obesity (Duncan, Aldstadt, Whalen, Melly, \& Gortmaker, 2011; Centers for Disease Control and Prevention, 2011; Hwang, Hurvitz, \& Duncan, 2016; Xu \& Wang, 2015; Jackson, 2003). Research has identified a number of streetscape features that promote pedestrian activity. For example, studies have found a positive relationship between pedestrian activity and: pedestrian-oriented infrastructure, such as the presence and condition of sidewalks, street lights, and benches (Shay, Spoon, \& Khattak, 2003;
Sallis et al., 2015; Ewing, Hajrasouliha, Neckerman, Purciel-Hill, \& Greene, 2015; Painter, 1996); slower speeds and fewer cars (Shay et al., 2003); and visual appeal, such as street cleanliness and the presence of trees (Zandieh, Martinez, Flacke, Jones, \& van Maarseveen, 2016; Sallis et al., 2015). Some studies have found an association between these streetscape features and socioeconomic factors: lower income neighborhoods often have fewer and/or poorer quality streetscape features, which can discourage walking (Gibbs, Slater, Nicholson, Barker, \& Chaloupka, 2012, Neckerman et al., 2009).

Health has increasingly become a consideration in built environment policy development, planning, and evaluation. Examples in California 
include: the adoption of health elements to several jurisdictions' General Plans (including the cities of Los Angeles, El Monte, and Lemon Grove); the use of Health Impact Assessments to systematically estimate the potential health effects of a proposed policy, program, or, project (Corburn, 2009; Los Angeles County Department of Public Health, 2019); the requirement by several State agencies for funding recipients to describe possible impacts to public health (California Health in All Policies Taskforce, 2018); and the development and adoption of new spatial tools to identify health-related data (Public Health Alliance of Southern California, 2019). Despite the consideration of health in many facets of built environment planning, policy, and implementation, local health departments often have minimal to no involvement in the regular evaluation of individual street-level projects. Instead, regular and ongoing evaluation is typically led by transportation or public works departments. Consequently, streetscape modification studies usually assess the impact of the modifications from a transportation or planning perspective. If health is assessed, it is often in terms of injuries, such as a decrease in the number of pedestrian-motorist collisions (Nielson, McClain, \& Hennessey, 2015; Federal Highway Administration, 2015); few analyze the streetscape modification's potential or observed impact on health-promoting behaviors such as physical activity (Dannenberg \& Wendel, 2011; McCormack \& Shiell, 2011). Incorporating a health lens into built environment evaluations could help agencies identify opportunities to maximize positive project outcomes.

\section{The Current Study}

This paper presents a case study of how the Los Angeles County Department of Public Health (DPH) worked with the City of Los Angeles to apply a health lens to evaluate a commercial corridor in Los Angeles that was undergoing streetscape modifications. Our work on this project was influenced by the concept of "Health in All Policies" (HiAP), an approach that promotes the incorporation of health considerations into decision-making across different sectors not traditionally associated with health (Rudolph, Caplan, Ben-Moshe, \& Dillon, 2013). In the current study, we sought to bring an
HiAP perspective to the evaluation of a built environment project that was being implemented by the Mayor's Office and the Los Angeles Department of Transportation (LADOT), to elevate the importance of health in understanding this project's impact.

In 2013, the Mayor of the City of Los Angeles launched the Great Streets Initiative, which selected one street in each of Los Angeles's 15 City Council districts to receive streetscape modifications, along with events to build awareness of the modifications (Great Streets Studio, 2017). One of the selected streets was a nearly one-mile section of César Chávez Avenue, a commercial corridor in the Boyle Heights neighborhood. This neighborhood is predominantly Latino and low-income, with high rates of obesity and diabetes (UCLA Center for Health Policy Research, 2014). The César Chávez Avenue corridor is part of Los Angeles's High Injury Network, meaning it has high rates of severe and fatal collisions between motorists and pedestrians or bicyclists (Los Angeles Department of Transportation, 2017). During 2015-2016, signalized intersections on César Chávez Avenue received painted curb extensions as part of the Great Streets Initiative.

A curb extension is a physical extension of a curb at a corner that is intended to reduce the pedestrian crossing distance, increase visibility between pedestrians and motorists, and reduce the speed of turning vehicles, all of which may increase pedestrian safety and encourage motorists to drive more carefully (Huang \& Cynecki, 2001; National Association of City Transportation Officials, 2017). Curb extensions are typically made of concrete, but the curb extensions installed on César Chávez were created by using red paint on the portion of the street where a concrete curb extension would be, bordering the extension with white paint and flexible bollards, and adding planters in the extensions (Figure 1). Research specifically on painted curb extensions is limited, and existing research on concrete curb extensions has produced mixed evidence on whether the extensions can improve pedestrian safety (e.g., by reducing pedestrian-motorist collisions at intersections) (Huang \& Cynecki, 2001; King, 
Figure 1. Intersection of St. Louis and César Chávez Avenue before (far left) and after (middle) installation of a painted curb extension, compared to a concrete curb extension (far right).
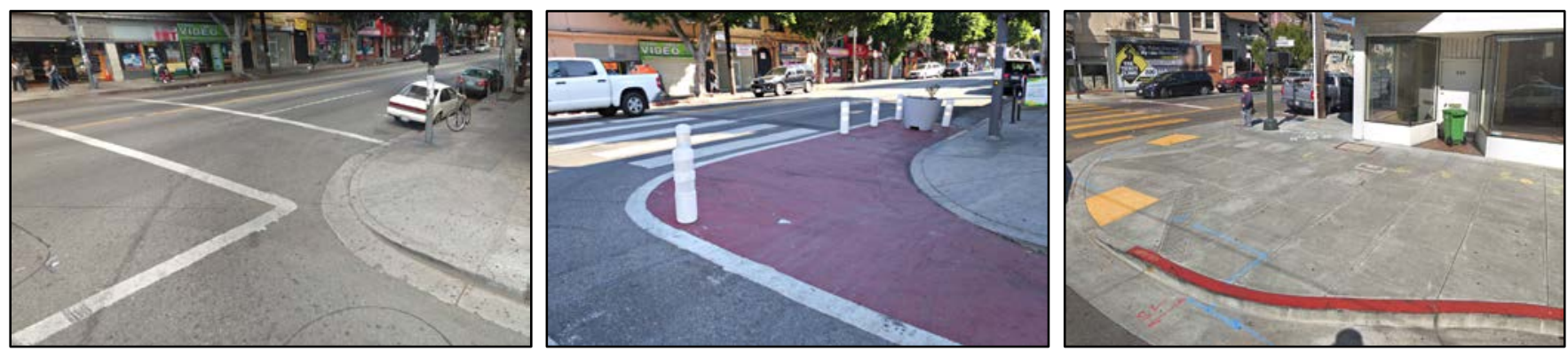

1999; Mead, Zegeer, \& Bushell, 2014; National Association of City Transportation Officials, 2017). In fall 2015, DPH collaborated with the Mayor's Office and LADOT to develop a healthfocused assessment of the painted curb extensions along the César Chávez corridor. We wanted to determine the influence of the painted curb extensions on pedestrian activity, such as walking, as this could lead to improved health conditions related to chronic disease or physical fitness. Early stage evidence pointing to healthy behavior change could include increased pedestrian volumes, safer pedestrian and motorist behavior at intersections with the extensions, and lower motorist speeds along the corridor. With scant precedent for a health-focused assessment of streetscape modifications, this evaluation was an opportunity to develop and test our methods, data collection techniques, and tools for assessing the connections between the built environment and health.

\section{Methods}

\section{Study Design}

This observational pre-post study collected quantitative data before and after the installation of a painted curb extension at one intersection, using a second intersection that already had the painted curb extension as a comparison site. Using diverse data collection methods at multiple time periods and at multiple sites along the César Chávez corridor, we sought to a) identify pedestrian and motorist behavior before and after the installation of a painted curb extension, b) characterize the users of the corridor, and c) describe additional built environment features of the corridor that may affect pedestrian activity.

\section{Setting}

Data collection for the streetscape modification project occurred along the César Chávez Avenue corridor between November 2015 and August 2016. For intersection-specific data, we selected two intersections located about a half-mile apart: St. Louis Street and César Chávez Avenue ("St. Louis"), and Mott Street and César Chávez Avenue ("Mott"). At baseline data collection, St. Louis had already received the painted curb extension. At follow-up, both intersections had painted curb extensions.

\section{Measures and Data Collection}

LADOT did not have an established data collection or evaluation protocol for curb extensions and had not engaged in data collection on this feature to date. Therefore, the instruments we selected supported our intention to understand the influence of the intervention on pedestrian activity (including walkability), as well as LADOT's safety goals. Table 1 summarizes the measures in this study. Most of the data collection tools have been used in either an evaluation or surveillance capacity elsewhere in California, while DPH adapted an existing tool to record pedestrian behavior at intersections.

Observation Strategies Utilized. Following established methodology, baseline and follow-up data collection primarily occurred during peak weekday hours in the morning (7-9 am) and afternoon (4-6 pm), and midday on weekends (11 am-1 pm) (Southern California Association of Governments and Metro, 2013; San Francisco Municipal Transportation Agency, 2015), for three weekdays and one weekend day (Los Angeles Department of Transportation, 2014). In 
such protocols, the length of the recommended observation period varies, but two hours is often suggested; too long of an observation period may lead to diminishing data collector accuracy (Southern California Association of Governments and Metro, 2013; Los Angeles Department of Transportation, 2014). In this study, limited staff capacity necessitated that some tools use a shorter observation period of one hour. Existing guidance acknowledges the likely challenge of limited resources, but recommends continuing with data collection activity even in these circumstances (Southern California Association of Governments and Metro, 2013).

We counted individuals as pedestrians based on the definition in the California Vehicle Code, which states that a pedestrian can be a person who is afoot, or who uses: a) a means of conveyance propelled by human power other than a bicycle, or b) an electric personal assistive mobility device (California Vehicle Code, 2008).

Pedestrian Volumes. We used three measures related to pedestrians. First, pedestrian volumes were continuously collected through two automated passive infrared pedestrian counters installed on either side of the block immediately east of Mott. The data collected were transmitted daily in 15-minute intervals to an online web portal. The ability of the counters to continuously count pedestrians for 24 hours a day was beneficial to understanding long-term patterns in pedestrian activity. However, given that the counters capture data based on heat sensors, the counters may count large dogs, or may record pedestrians walking side-by-side as one person.

Pedestrian and Bicyclist Characteristics. To complement the capabilities of the counters, we collected in-person baseline data on pedestrian and bicyclist volumes and characteristics using screenline count forms developed by the Southern California Association of Governments and the Los Angeles County Metropolitan Transportation Authority. Two data collectors recorded this data while positioned next to the automated counters near Mott. Pedestrian characteristics included children, individuals using a wheelchair or other assistive mobility device, and individuals using a skateboard, scooter, or skates. Bicyclist characteristics included females, individuals riding on the sidewalk, and individuals wearing no helmet.

Pedestrian Behavior Observations. We adapted a pedestrian behavior observation tool from LADOT, to collect baseline and follow-up data at St. Louis and Mott. Demographic data collected included age (under 16, 16-65, over 65) and gender (male or female). Crosswalk behavior data included the location where pedestrians waited to cross the street (e.g., on the sidewalk, in the painted curb extension, or in the street) and the signal status when pedestrians began crossing (e.g., walk signal, flashing red, solid red, or a light mismatch [if no pedestrian pushed the walk signal button, then the walk signal did not turn on when the traffic light turned green]). The same pedestrian could have been counted more than once, if they crossed multiple crosswalks during an observation period. At baseline, one data collector recorded this data; due to high pedestrian volumes, two data collectors were assigned to gather this data at follow-up.

Motorist Behavior. We used two measures to examine motorist behavior. First, two data collectors used a tool developed by LADOT in order to collect data on two types of motorist noncompliance at the St. Louis and Mott intersections: failure to yield (a motorist turns into a crosswalk before a pedestrian has safely passed the centerline), and encroachment (a motorist enters the crosswalk area during a red signal phase). A pedestrian must be in the crosswalk in order to warrant a "failure to yield"; however, encroachment was counted whether or not a pedestrian was crossing. These types of motorist behavior can discourage pedestrian activity (Goddard, Kahn, \& Adkins, 2014; Jacobsen, Racioppi, \& Rutter, 2010).

Car Speeds. We used speed radar equipment from the Los Angeles County Department of Public Works (DPW) to capture the speed of passing cars along the block immediately east of Mott, to understand if there was a substantial change in speed after the installation of the painted curb extension at Mott. Using established methodology by DPW, one data collector sat in a parked car and gathered speed data for 100 cars 
in each observation period (50 cars heading in each direction), typically capturing the speed of the first car in a string of cars, since the first car generally sets the pace for all those that follow it. During baseline, the nearest painted curb extension was more than a quarter-mile away to the west. During follow-up, Mott had received painted curb extensions.

Built Environment Characteristics. We used the Pedestrian Environmental Quality Index (PEQI) to gather information about the quality of the built environment along the Great Streets corridor as it relates to walkability. The PEQI was originally developed by the San Francisco Department of Public Health and was later adapted by the Sustainable Technology and Policy Program at the University of California, Los Angeles for use in Southern California. Two versions of the PEQI exist: one for intersections, and one for street segments (e.g., blocks). Scores range from 0 to 100 , with higher numbers representing better pedestrian conditions.

Table 1.

Summary of Data Collection Activities

\begin{tabular}{|c|c|c|c|c|c|}
\hline $\begin{array}{l}\text { Type of Data } \\
\text { Collected }\end{array}$ & Purpose & $\begin{array}{l}\text { Data Collection } \\
\text { Tool }\end{array}$ & $\begin{array}{l}\text { Data Collection } \\
\text { Dates }\end{array}$ & $\begin{array}{l}\text { Data Collection } \\
\text { Hours }\end{array}$ & Location $^{1}$ \\
\hline $\begin{array}{l}\text { Pedestrian } \\
\text { volumes }\end{array}$ & $\begin{array}{l}\text { Count the number } \\
\text { of pedestrians }\end{array}$ & $\begin{array}{l}\text { Automated passive } \\
\text { infrared pedestrian } \\
\text { counters }\end{array}$ & $\begin{array}{l}\text { Continuous: } \\
\text { Nov. 12, 2015 - } \\
\text { Aug. 31, } 2016\end{array}$ & 24 hours a day & $\begin{array}{l}\text { Mott to } \\
\text { Saratoga }\end{array}$ \\
\hline $\begin{array}{l}\text { Manual counts of } \\
\text { pedestrians, } \\
\text { bicyclists, and } \\
\text { related } \\
\text { characteristics }\end{array}$ & $\begin{array}{l}\text { Understand } \\
\text { individual-level } \\
\text { characteristics of } \\
\text { corridor users }\end{array}$ & $\begin{array}{l}\text { Count forms by SCAG and } \\
\text { Metro }^{2}\end{array}$ & $\begin{array}{l}\text { Nov. 17-19, } 2015 \text { (Tues- } \\
\text { Thurs) }\end{array}$ & $\begin{array}{l}7-9 \mathrm{am} \\
4-6 \mathrm{pm}\end{array}$ & $\begin{array}{l}\text { Mott to } \\
\text { Saratoga } \\
\text { Mott to } \\
\text { Saratoga }\end{array}$ \\
\hline \multirow[t]{2}{*}{$\begin{array}{l}\text { Pedestrian } \\
\text { behavior at } \\
\text { intersections and } \\
\text { characteristics }\end{array}$} & $\begin{array}{l}\text { Observe if } \\
\text { pedestrian crossing } \\
\text { behavior differed } \\
\text { with and without } \\
\text { painted curb } \\
\text { extension }\end{array}$ & $\begin{array}{l}\text { Pedestrian behavior } \\
\text { observation count form } \\
\text { developed by DPH; } \\
\text { partially adapted from } \\
\text { LADOT People St } \\
\text { Evaluation toolkit }^{3}\end{array}$ & $\begin{array}{l}\text { Baseline: } \\
\text { Jan. 6-8, } 2016 \\
\text { (Wed-Fri) }\end{array}$ & $\begin{array}{l}7-8 \mathrm{am} \\
8: 15-9: 15 \mathrm{am} \\
4-5 \mathrm{pm} \\
5: 15-6: 15 \mathrm{pm}\end{array}$ & $\begin{array}{l}\text { St. Louis } \\
\text { Mott } \\
\text { St. Louis } \\
\text { Mott }\end{array}$ \\
\hline & & & Jan. 9, 2016 (Sat) & $\begin{array}{l}11 \mathrm{am}-12 \mathrm{pm} \\
12: 15-1: 15 \mathrm{pm}\end{array}$ & $\begin{array}{l}\text { St. Louis } \\
\text { Mott }\end{array}$ \\
\hline $\begin{array}{l}\text { Motorist non- } \\
\text { compliance at } \\
\text { intersections }\end{array}$ & $\begin{array}{l}\text { Observe if motorist } \\
\text { behavior at } \\
\text { intersections } \\
\text { differed with and } \\
\text { without painted } \\
\text { curb extension }\end{array}$ & $\begin{array}{l}\text { Non-compliant motorist } \\
\text { intersection count form } \\
\text { developed by DPH; } \\
\text { partially adapted from } \\
\text { LADOT People St } \\
\text { Evaluation toolkit }\end{array}$ & $\begin{array}{l}\text { Follow-Up: } \\
\text { May 21, } 2016 \\
\text { (Sat) } \\
\text { May 24-26, } 2016 \\
\text { (Tues-Thurs) }\end{array}$ & $\begin{array}{l}11 \mathrm{am}-12 \mathrm{pm} \\
12: 15-1: 15 \mathrm{pm} \\
7-8 \mathrm{am} \\
8: 15-9: 15 \mathrm{am} \\
4-5 \mathrm{pm} \\
5: 15-6: 15 \mathrm{pm}\end{array}$ & $\begin{array}{l}\text { St. Louis } \\
\text { Mott } \\
\text { St. Louis } \\
\text { Mott } \\
\text { St. Louis } \\
\text { Mott }\end{array}$ \\
\hline $\begin{array}{l}\text { Motorist speed } \\
\text { observations }\end{array}$ & $\begin{array}{l}\text { Measure motorist } \\
\text { speed near } \\
\text { intersection before } \\
\text { and after } \\
\text { installation of } \\
\text { painted curb } \\
\text { extension } \\
\end{array}$ & $\begin{array}{l}\text { Manual speed survey } \\
\text { using speed radar } \\
\text { equipment loaned by the } \\
\text { Los Angeles County } \\
\text { Department of Public } \\
\text { Works }\end{array}$ & $\begin{array}{l}\text { Baseline: } \\
\text { Jan. 6-9, } 2016 \\
\text { (Wed-Sat) } \\
\text { Follow-Up: } \\
\text { May 21 (Sat) \& 24-26 } \\
\text { (Tues-Thurs), 2016 }\end{array}$ & Begin at 11 am & $\begin{array}{l}\text { Mott to } \\
\text { Saratoga }\end{array}$ \\
\hline $\begin{array}{l}\text { Inventory of built } \\
\text { environment } \\
\text { quality related to } \\
\text { walkability }\end{array}$ & $\begin{array}{l}\text { Describe built } \\
\text { environment along } \\
\text { the corridor in } \\
\text { terms of walkability }\end{array}$ & $\begin{array}{l}\text { Pedestrian Environmental } \\
\text { Quality Index, developed } \\
\text { by San Francisco } \\
\text { Department of Public } \\
\text { Health and adapted by } \\
\text { University of California, } \\
\text { Los Angeles }\end{array}$ & Jan. 8, 2016 (Fri) & $\begin{array}{l}\text { During daylight } \\
\text { hours }\end{array}$ & $\begin{array}{l}\text { César Chávez } \\
\text { between St. } \\
\text { Louis and } \\
\text { Evergreen }\end{array}$ \\
\hline
\end{tabular}

1 “St. Louis”: intersection of St. Louis and César Chávez; "Mott”: intersection of Mott and César Chávez; "Mott to Saratoga”: block of César Chávez between Mott and Saratoga

2 SCAG: Southern California Association of Governments; Metro: Los Angeles County Metropolitan Transportation Authority

${ }^{3}$ DPH: Los Angeles County Department of Public Health; LADOT: Los Angeles Department of Transportation

\section{Data Analyses}

We conducted descriptive analyses to achieve two goals. First, we wanted to describe pedestrian and bicyclist volumes and demographics at Mott, where the painted curb extension was installed during the study period. Second, we sought to 
understand pedestrian and motorist behavior before and after the painted curb extension was installed at Mott, and to compare these findings to observations at St. Louis, where the painted curb extension had been in place throughout the study period. We conducted a difference-indifference analysis to identify if motorist behavior changed significantly between data collection periods and between data collection sites. We compared PEQI scores for individual intersections and street segments, and tabulated the extent to which streetscape elements were present along the corridor. All analyses were performed using Stata 14.2 (Stata Corp LP, College Station, Texas).

\section{Results}

\section{Pedestrian Volumes}

Results show that the César Chávez corridor is heavily used by pedestrians. Over the course of ten months, automated counters at Mott tallied a daily average of 1,689 pedestrians: 1,626 before the painted curb extension was installed (standard deviation: 241; range: 816-2,428), and 1,722 after installation (standard deviation: 387; range: $1,201-4,844)$. The increase is largely attributable to high pedestrian volumes in mid-April, concurrent with tax season, as a tax preparation site was located on this observation block: on the day before taxes were due, 4,844 pedestrians were counted, well above the follow-up average. Significant dips in volume generally aligned with major holidays and rainy weather.

\section{Pedestrian and Bicyclist Characteristics}

Baseline in-person counts at Mott (Table 2) showed that two-hour pedestrian volumes were highest on the weekend (386 pedestrians) and weekday afternoons (average of 310 pedestrians). Few of these pedestrians were: a) using a wheelchair or other assistive devices, or b) using a skateboard, scooter, or skates. Among pedestrians, children were most frequently observed on the weekend $(n=77)$. Bicyclist volume was highest in the afternoon (average of 25 bicyclists); most were male, rode on the sidewalk, and wore no helmet.

\section{Pedestrian Behavior}

Demographic results from pedestrian behavior observations (Table 2) showed that at both intersections, over half of pedestrians were male, though the gap narrowed slightly at follow-up. In terms of age, the share of pedestrians over 65 increased at follow-up for both intersections.

Pedestrian crossing behavior changed slightly between baseline and follow-up (Table 2). At St. Louis, $0.9 \%$ of pedestrians waited in the extension to cross the street; this increased to 3.6\% at follow-up. At Mott, where there had been no painted curb extension during baseline, $2.4 \%$ of pedestrians waited in the extension during follow-up. Most pedestrians exhibited safe crossing behavior: at both intersections and at both time periods, approximately $85 \%$ of pedestrians began crossing when the walk signal was on. However, at follow-up, when both intersections had painted curb extensions, there was an increased share of pedestrians that began crossing when the walk signal was flashing red (pedestrians should not begin crossing when this signal is active). 
Table 2

Pedestrian Volume, Crossing Behavior, and Demographics on César Chávez Avenue, Los Angeles Manual pedestrian/bicyclist two-hour counts on the block immediately east of Mott and César Chávez Avenue, Los Angeles, November 2015

$\begin{array}{lcccccc}\text { Time period } & \begin{array}{c}\text { Mean number of } \\ \text { total pedestrians }{ }^{1}(\mathrm{SD})^{2}\end{array} & \text { Min } & \text { Max } & \begin{array}{c}\text { Mean number of } \\ \text { bicyclists }^{1}(\mathrm{SD})\end{array} & \text { Min } & \text { Max } \\ 7-9 \mathrm{am} & 134(50) & 83 & 182 & 11(1) & 10 & 11 \\ 11 \mathrm{am}-1 \mathrm{pm} & 386(\mathrm{~N} / \mathrm{A}) & \text { N/A } & \text { N/A } & 11(\mathrm{~N} / \mathrm{A}) & \text { N/A } & \text { N/A } \\ 4-6 \mathrm{pm} & 310(55) & 247 & 351 & 25(2) & 23 & 27\end{array}$

Pedestrian crossing behavior and demographics at intersections of St. Louis/César Chávez Avenue and Mott/César Chávez Avenue, Los Angeles, January and May $2016^{3}$

\begin{tabular}{|c|c|c|c|c|c|c|}
\hline & \multicolumn{2}{|c|}{ Overall } & \multicolumn{2}{|c|}{ St. Louis } & \multicolumn{2}{|c|}{ Mott } \\
\hline \multicolumn{7}{|c|}{ Pedestrian waiting location } \\
\hline \multirow{3}{*}{ Baseline } & Sidewalk & $99.2 \%(1,676)$ & Sidewalk & $98.6 \%$ (898) & Sidewalk & $100 \%(778)$ \\
\hline & Extension & $0.5 \%(8)$ & Extension & $0.9 \%(8)$ & Extension & N/A \\
\hline & Street & $0.3 \%(5)$ & Street & $0.6 \%(5)$ & Street & $0 \%(0)$ \\
\hline \multirow[t]{3}{*}{ Follow-Up } & Sidewalk & $96.4 \%(3,751)$ & Sidewalk & $96.0 \%(2,309)$ & Sidewalk & $97.2 \%(1,442)$ \\
\hline & Extension & $3.4 \%(131)$ & Extension & $4.0 \%(95)$ & Extension & $2.4 \%(36)$ \\
\hline & Street & $0.2 \%(8)$ & Street & $0.1 \%(2)$ & Street & $0.4 \%(6)$ \\
\hline
\end{tabular}

Signal status when pedestrian began crossing

\begin{tabular}{|c|c|c|c|c|c|c|}
\hline \multirow[t]{4}{*}{ Baseline } & Walk & $84.3 \%(1,424)$ & Walk & 83.5\% (761) & Walk & $85.2 \%(663)$ \\
\hline & Flashing & $6.1 \%(103)$ & Flashing & $7.1 \%(65)$ & Flashing & $4.9 \%$ \\
\hline & Solid & $1.9 \%(32)$ & Solid & $2.1 \%(19)$ & Solid & $1.7 \%(13)$ \\
\hline & Mismatch & $7.7 \%(130)$ & Mismatch & $7.2 \%(66)$ & Mismatch & $8.2 \%(64)$ \\
\hline \multirow[t]{4}{*}{ Follow-Up } & Walk & $85.0 \%(3,242)$ & Walk & $85.5 \%(1,988)$ & Walk & $84.2 \%(1,254)$ \\
\hline & Flashing & $10.3 \%(394)$ & Flashing & $11.1 \%$ (259) & Flashing & $9.1 \%(135)$ \\
\hline & Solid & $1.6 \%(61)$ & Solid & $1.3 \%(30)$ & Solid & $2.1 \%(31)$ \\
\hline & Mismatch & $3.1 \%(118)$ & Mismatch & $2.1 \%(49)$ & Mismatch & $4.6 \%$ (69) \\
\hline \multicolumn{7}{|l|}{ Gender } \\
\hline \multirow[t]{2}{*}{ Baseline } & Female & $42.0 \%$ (709) & Female & $40.5 \%$ (369) & Female & $43.7 \%(340)$ \\
\hline & Male & $58.0 \%(980)$ & Male & $59.5 \%$ (542) & Male & $56.3 \%(438)$ \\
\hline \multirow[t]{2}{*}{ Follow-Up } & Female & $46.3 \%(1,813)$ & Female & $46.3 \%(1,122)$ & Female & $46.3 \%$ (691) \\
\hline & Male & $53.7 \%(2,103)$ & Male & $53.7 \%(1,301)$ & Male & $53.7 \%(802)$ \\
\hline \multicolumn{7}{|l|}{ Age } \\
\hline \multirow[t]{3}{*}{ Baseline } & Under 16 & $16.2 \%(273)$ & Under 16 & $16.7 \%(152)$ & Under 16 & $15.6 \%(121)$ \\
\hline & $16-65$ & $74.4 \%(1,257)$ & $16-65$ & $75.3 \%(686)$ & $16-65$ & $73.4 \%(571)$ \\
\hline & Over 65 & $9.4 \%(159)$ & Over 65 & $8.0 \%(73)$ & Over 65 & $11.1 \%(86)$ \\
\hline \multirow[t]{3}{*}{ Follow-Up } & Under 16 & 20.7\% (809) & Under 16 & $22.2 \%(536)$ & Under 16 & $18.3 \%(273)$ \\
\hline & $16-65$ & $65.2 \%(2,546)$ & $16-65$ & $62.6 \%(1,512)$ & $16-65$ & $69.4 \%(1,034)$ \\
\hline & Over 65 & $14.0 \%(548)$ & Over 65 & $15.2 \%(366)$ & Over 65 & $12.2 \%$ \\
\hline
\end{tabular}




\section{Motorist Behavior}

Table 3 summarizes motorist behavior. Failure to yield remained generally consistent between baseline and follow-up at both intersections. Encroachment incidents increased at St. Louis between baseline (10.57) and follow-up (15.00), but decreased at Mott (from 24.57 to 17.43). Difference-in-difference analyses found no statistically significant change for failure to yield (co-efficient: -0.43 , standard error: 1.77, p- value $=0.81$ ) or encroachment (co-efficient: -11.57, standard error: 7.75, p-value $=0.15$ ). Speeding near Mott remained generally consistent across time periods, at an average of approximately 30 miles per hour (the posted speed limit for this corridor). Fewer eastbound cars traveled above the speed limit at follow-up (44\%) compared to baseline (50\%), while more westbound cars exceeded the speed limit at follow-up (40\%) compared to baseline (33\%).

Table 3.

Motorist behavior along César Chávez Avenue, Los Angeles, 2015-2016

\begin{tabular}{|c|c|c|c|c|c|}
\hline \multicolumn{6}{|c|}{ Average number of motorist non-compliance incidents in a one-hour period } \\
\hline & \multicolumn{2}{|c|}{$\begin{array}{c}\text { Baseline } \\
\text { Mean }(\mathrm{SD})^{1}\end{array}$} & \multicolumn{3}{|c|}{$\begin{array}{l}\text { Follow-Up } \\
\text { Mean (SD) }\end{array}$} \\
\hline \multicolumn{6}{|l|}{ St. Louis } \\
\hline Number of drivers failing to yield & \multicolumn{2}{|c|}{$3.86(2.85)$} & \multicolumn{3}{|c|}{$3.43(2.23)$} \\
\hline Number of drivers encroaching & \multicolumn{2}{|c|}{$10.57(4.39)$} & \multicolumn{3}{|c|}{$15.00(8.00)$} \\
\hline \multicolumn{6}{|l|}{ Mott } \\
\hline Number of drivers failing to yield & \multicolumn{2}{|c|}{$2.71(2.50)$} & \multicolumn{3}{|c|}{$1.86(1.57)$} \\
\hline Number of drivers encroaching & \multicolumn{2}{|c|}{$24.57(15.70)$} & \multicolumn{3}{|c|}{$17.43(9.54)$} \\
\hline \multicolumn{6}{|c|}{ Speed observations on the block immediately east of Mott } \\
\hline Time period & $\begin{array}{r}\text { Mean miles } \\
\text { per hour (SD) }\end{array}$ & Min & Max & \multicolumn{2}{|c|}{$\begin{array}{l}\text { Number of cars above } \\
\text { speed limit ( } 30 \mathrm{mph})\end{array}$} \\
\hline \multicolumn{6}{|l|}{ Baseline } \\
\hline $\begin{array}{l}\text { Eastbound }(n=200) \\
\text { Westbound }(n=199)\end{array}$ & $\begin{array}{l}28.3(5.2) \\
29.7(5.0)\end{array}$ & $\begin{array}{l}11 \\
21\end{array}$ & $\begin{array}{l}42 \\
46\end{array}$ & & $\begin{array}{l}99(50 \%) \\
66(33 \%)\end{array}$ \\
\hline \multicolumn{6}{|l|}{ Follow-up } \\
\hline Eastbound (n=200) & $29.8(5.2)$ & 14 & 46 & & $88(44 \%)$ \\
\hline Westbound (n=200) & $30.03(6.0)$ & 13 & 60 & & $80(40 \%)$ \\
\hline
\end{tabular}

${ }^{1}$ Standard deviation

\section{Built Environment Characteristics}

The quality of the pedestrian environment was lower on average at intersections (mean PEQI score of 41.52, standard deviation: 19.93, range: 12.5-71.43) than along street segments (mean: 58.49, standard deviation: 5.92, range: 47.9567.82). Results from the PEQI tool revealed that the corridor had many streetscape features that could pose challenges to pedestrians, including broken sidewalks, significant litter, insufficient pedestrian lighting, and scarce public seating (Table 4).

We compared our PEQI findings with community feedback data collected by Nuestra Avenida (an umbrella group of local, community-based organizations) along the Great Streets corridor. Nuestra Avenida shared their results with us to augment findings from our data collection activities, so we could avoid oversaturating the community by conducting our own separate survey during the same timeframe. We were not involved in Nuestra Avenida's survey design, implementation, data entry, or data cleaning. Nuestra Avenida's results were the product of two different data collection activities. First, in fall 2015, Nuestra Avenida hosted two community events in which they shared printed images of proposed streetscape modifications and asked participants $(n=90)$ to identify their top three choices and suggest any additional desired modifications. Second, in spring 2016, Nuestra Avenida held a street fair in which they installed 
several pop-up streetscape modifications throughout the corridor, and surveyed over 200 street fair attendees for opinions about the pop-up installations, other opportunities for improvement along the corridor, and pedestrian safety.

We found that Nuestra Avenida's results aligned with our PEQI findings. Most survey respondents favored streetscape modifications such as better sidewalk conditions and more trash cans, citing uneven pavement and unclean streets; these had also emerged as primary issues in the PEQI. Curb extensions were not among the top street enhancement features prioritized by community members, though nearly all (89\%) of those surveyed said they felt safer with the painted curb extensions. Community members also voiced concerns about pedestrian safety in the face of dangerous driver behavior, such as running red lights or speeding.

Table 4.

Pedestrian Environmental Quality Index along César Chávez Avenue, Los Angeles, January 2016 Intersection Segment

\begin{tabular}{lrlr}
\hline $\begin{array}{l}\text { Selected intersection } \\
\text { characteristics }\end{array}$ & $\begin{array}{r}\text { \# intersections } \\
(14 \text { total })\end{array}$ & $\begin{array}{l}\text { Selected segment } \\
\text { characteristics }\end{array}$ & $\begin{array}{r}\text { \# segments } \\
(17 \text { total })\end{array}$ \\
\hline Average pedestrian crossing time & 22.25 seconds & No litter & $0(0 \%)$ \\
“No turn on red” signal or sign & $0(0 \%)$ & Little/no noise & $2(6 \%)$ \\
Pedestrian signs & $3(21 \%)$ & Speed limit sign posted & $5(29 \%)$ \\
$\begin{array}{l}\text { Presence of an intersection traffic } \\
\text { calming feature }\end{array}$ & $5(36 \%)$ & Pedestrian lighting \\
$\begin{array}{l}\text { Pedestrian signal countdown at } \\
\text { intersections w/ traffic signals }\end{array}$ & $8(100 \%)$ & Sidewalk condition: no & $5(29 \%)$ \\
$\begin{array}{l}\text { Stop signs at intersections without traffic } \\
\text { signals }\end{array}$ & $6(100 \%)$ & Public seating/bus bench & $7(41 \%)$ \\
\hline
\end{tabular}

\section{Discussion}

The data suggest that the streetscape modification did not significantly influence health through increased pedestrian activity, though some slight changes were observed. While specific results from the César Chávez corridor assessment may not be generalizable to all jurisdictions, the lessons learned from both the evaluation process and the experience working across disciplines can be valuable for practitioners seeking to incorporate health considerations into built environment projects in their jurisdictions.

If you build it, they may not come: Streetscape modifications need to be designed and implemented with users in mind. Our study found that the installation of the painted curb extension at Mott did not appear to significantly impact pedestrian and motorist behavior. The lack of substantive behavior change may be partly attributable to users of the corridor not recognizing that the paint, bollards, and planters represented a curb extension where pedestrians could stand; there was no explanatory signage posted. The ambiguity may have been compounded by the use of red paint for the curb extension: given that curbs are typically painted red in locations where parking is not allowed, corridor users may have assumed that the red paint of the curb extension similarly meant that people are not allowed to stand in it. A different color may have more clearly indicated that pedestrian usage of the curb extension was permitted. But while the painted curb extensions in this case study did not show evidence of markedly promoting pedestrian activity (e.g., walking) that could improve health, it is possible that a suite of streetscape modifications would have collectively made a measurable difference. Local health departments are well positioned to 
help identify which combination of streetscape modifications could promote healthy behaviors.

Relationship-building and coordination of evaluation capabilities were public health contributions that facilitated interagency collaboration. DPH staff have long been cultivating relationships with departments in the City of Los Angeles that are involved in built environment work, such as the Mayor's Office and its Great Streets Program, LADOT, and the Department of City Planning. DPH has provided funding to support the City's efforts to develop or update community plans, including several transit-oriented development plans (Los Angeles County Department of Public Health, 2015) and a new Health and Wellness Element for the city's General Plan (The Plan for a Healthy Los Angeles, 2015). DPH has also assisted in facilitating workshops that support other citywide initiatives, such as Vision Zero, which strives to eliminate traffic deaths by 2025 (Vision Zero, 2017). These investments have helped establish trust and a sustained relationship with City staff, fostering ongoing opportunities to collaborate. The time invested in the relationship-building process contributed to the success of the present assessment: when DPH came to the City with the proposed health-focused evaluation of the César Chávez corridor, the City was immediately receptive.

Over the course of the project, we provided data to partners in several forms: a baseline and follow-up report with detailed results, and a public-facing data brief that summarized highlevel results for distribution to community-based organizations working near the César Chávez corridor. These products were intended to help partners ground their work in relevant, current, local data that included a health lens. The City asked us to write a section for their 15 Great Streets Baseline Evaluation Report explicitly making the connection between health and the built environment, and requested health indicators (e.g., neighborhood chronic disease prevalence rates) for their assessment of all 15 Great Streets sites. These examples represent ways in which health considerations can become better integrated into built environment projects, and ultimately become a standard component of such projects.

Flexibility was a key element in the evaluation process. Being flexible and readily adapting to changes became crucial to the César Chávez assessment. Throughout the study, timing was often beyond our control — for example, LADOT determined the timing of the intervention's installation. As a result, we adjusted baseline and follow-up data collection dates to align with LADOT's installation schedule, which changed on short notice. While this meant that we had to collect baseline data in winter instead of spring (i.e., rainier weather and shorter daylight hours), it was critical for us to be able to modify and mobilize quickly in order to collect data before the painted curb extension at Mott was installed.

Identifying a pipeline or ongoing series of new projects may sustain the momentum and strengthen the collaboration after the original project has ended. After the conclusion of an evaluation that involves interagency collaboration, intentional efforts are required to engage the different agencies on a consistent basis, especially given each agency's competing needs, priorities, deadlines, and funding streams. Our continued participation in collaborative activities such as Vision Zero committees and the Great Streets Working Group can help sustain the momentum to incorporate health considerations into other local built environment projects.

Meaningful community outreach and involvement in a place-based intervention can advance health equity. The City had envisioned the installation of the painted curb extensions largely from a safety perspective, rather than a broader goal of improving walkability. But Nuestra Avenida's data activities revealed that community members preferred other streetscape modifications more directly associated with walkability, such as better sidewalk conditions and more trash cans, over the painted curb extensions. Their preferred streetscape modifications aligned with our PEQI inventory. This community feedback was gathered after the installation of the painted curb extensions began. The Boyle Heights community has had ongoing 
concerns about displacement and gentrification, which research has shown can lead to negative health impacts (Causa Justa :: Just Cause and the Alameda County Public Health Department Place Matters Team, 2014). In light of this, involving the community in designing their own streets can help advance health equity. Local health departments can be a champion for meaningful community involvement at the early stages of a streetscape modification project (Minnesota Department of Health, Health Partnerships Division, 2016; Human Impact Partners, 2018).

Early and substantive community engagement can lead to streetscape modification designs that reflect both project goals and community needs, and can also promote greater buy-in from the community, which can lead to positive health impacts (Creighton, 2005; Corburn, 2009). Community members can be a valuable resource: their deep familiarity with their neighborhood makes them uniquely qualified to provide input on appropriate streetscape modifications (Adams \& Cavill, 2015). But if local organizations are not trained in appropriate data collection methods, then feedback from community members risks being disregarded because of data quality concerns. Local health departments can provide technical assistance to these organizations by providing resources and direction on data collection methods, such as: survey templates, a set of survey questions relevant to assessing specific project design and outcomes, or guidance on sampling strategies or participatory planning methods. Systematically gathering community feedback through structured data collection methods and tools can help ensure that the data are of high quality, accurately represent community views, and guide the streetscape design to promote healthier outcomes for the community.

\section{Limitations}

Several limitations should be considered in the context of this case study. First, timing was a challenge. Painted curb extensions had already been installed at some intersections along the corridor before we could begin baseline data collection, which prevented us from conducting a more rigorous and analytically sophisticated evaluation. Furthermore, due to a changing installation schedule, our baseline data collection had to be conducted in winter rather than spring; as such, rainier weather and shorter daylight hours may have affected pedestrian and motorist behavior. However, this issue was partially mitigated by the automated counters, which continuously captured pedestrian volumes for ten months, as seasons and daylight hours changed. Second, this study required significant staff time and resources. Data collection could not be conducted at both intersections simultaneously due to limited staff availability, which may have exaggerated differences in pedestrian and motorist behavior at the two intersections. Third, some data collection tools and protocols were moderately revised between baseline and followup, based on data collector experience and iterative feedback from the Mayor's Office and LADOT. The revisions improved data quality, but also may have affected observed differences between the two time periods. Identifying or designing a tool and protocol that will be used in the same form throughout the assessment should be a priority for other practitioners conducting health-focused assessments of streetscape modification projects (Pliakas et al., 2017).

\section{Conclusions}

This case study provides one example of how a local health department promoted an HiAP approach by incorporating a health lens into the evaluation of a street-level built environment project; additional examples of evaluation approaches (including methods, tools, and measures) can further contribute to the development of a practice-based model applicable across a broad range of projects, resources, and jurisdictions. In future streetscape modification projects, health departments or other health practitioners can be valuable collaborators throughout all three key phases of the project - design, implementation, and evaluation - to enhance health benefits to the community that the modifications are intended to serve. 


\section{Acknowledgements}

The authors thank the Great Streets Program at the City of Los Angeles's Mayor's Office and the Los Angeles Department of Transportation (LADOT) for their valuable support and feedback throughout the data collection period, as well as the data collectors from the Los Angeles County Department of Public Health, LADOT, and the Nuestra Avenida team. This evaluation was supported in part by a cooperative agreement from the Centers for Disease Control and Prevention (Award \#U58DP005509). The content and information presented in the paper do not necessarily reflect the views of the Los Angeles County Department of Public Health, the Centers for Disease Control and Prevention, or the City of Los Angeles.

\section{References}

Adams, E.J., \& Cavill, N. (2015). Engaging communities in changing the environment to promote transport-related walking: Evaluation of route use in the 'Fitter for Walking' project. Journal of Transport \& Health, 2(4), 580-594.

California Health in All Policies Task Force. (2018). Health in All Policies Task Force: 2014-2018 Active Transportation Action Report. Available at: http://sgc.ca.gov/programs/hiap/docs/20180803HiAP_Active_Transportation_Action_Report_July_2018.pdf.

California Vehicle Code. (2008). Vehicle Code Section 467. Available at: http://leginfo.legislature.ca.gov/faces/codes_displaySection.xhtml?lawCode=VEH\&sectionNum= 467.

Causa Justa: Just Cause and the Alameda County Public Health Department Place Matters Team. (2014). Development without displacement: Resisting gentrification in the Bay Area. Available at: http://www.acphd.org/media/343952/cjjc2014.pdf.

Centers for Disease Control and Prevention. (2011). Impact of the built environment on health. Available at: https://www.cdc.gov/nceh/publications/factsheets/impactofthebuiltenvironmentonhealth.pdf.

Corburn, J. (2009). Toward the Healthy City: People, Places, and the Politics of Urban Planning. The MIT Press, Cambridge.

Creighton, J.L. (2005). The public participation handbook: Making better decisions through citizen involvement. San Francisco: Jossey-Bass.

Dannenberg, A.L., \& Wendel, A.M. (2011). Measuring, assessing, and certifying healthy places. In A.L. Dannenberg, H. Frumkin, \& R.J. Jackson (Ed.), Making Healthy Places: Designing and Building for Health, Well-being, and Sustainability (pp. 303-317). Washington, DC: Island Press.

Duncan, D.T, Aldstadt, J., Whalen, J., Melly, S.J., \& Gortmaker, S.L. (2011). Validation of Walk Score ${ }^{\circledR}$ for estimating neighborhood walkability: An analysis of four US metropolitan areas. International Journal of Environmental Research and Public Health, 8(11), 4160-4179.

Ewing, R., Hajrasouliha, A., Neckerman, K.M., Purciel-Hill, M., \& Greene, W. (2015). Streetscape features related to pedestrian activity. Journal of Planning Education and Research, 36(1), 5-15.

Federal Highway Administration, U.S. Department of Transportation. (2015). Road Diet Case Studies. Available at: https://safety.fhwa.dot.gov/road_diets/case_studies/roaddiet_cs.pdf.

Federal Highway Administration, U.S. Department of Transportation. (2013). Curb Extensions. Available at: http://www.pedbikesafe.org/PEDSAFE/countermeasures_detail.cfm?CM_NUM=5.

Gibbs, K., Slater, S.J., Nicholson, N., Barker, D.C., \& Chaloupka, F.J. (2012). Income disparities in street features that encourage walking - A BTG Research Brief. Available at:

http://www.bridgingthegapresearch.org/_asset/02fpi3/btg_street_walkability_FINAL_03-0912.pdf.

Goddard, T., Kahn, K. B., \& Adkins, A. (2014). Racial bias in driver yielding behavior at crosswalks. NITC-SS-733. Portland, OR: Transportation Research and Education Center. Available at: https://pdxscholar.library.pdx.edu/cgi/viewcontent.cgi?article=1009\&context=psy_fac.

Google Maps. (2017). 555 Irving St, San Francisco, California. Available at: https://www.google.com/maps/place/7th+Ave+\%26+Irving+St,+San+Francisco,+CA+94122/@3 7.7641853,-122.464027,3a,75y,326.38h,80.84t/data=!3m6!1e1!3m4!1sN 
dE03Q1xLwFF6K1kNaDGZg!2e0!7i16384!8i8192!4m5!3m4!1s0x8085875c0cf5f6b1:0xd3606d 80ccf0130e!8m2!3d37.7641285!4d-122.4641993.

Google Maps. (2014). 459 N. Louis St, Los Angeles, California. Available at: https://www.google.com/maps/@34.0483494,118.211549,3a,75y,88.47h,75.85t/data=!3m6!1e1!3 m4!1s_4awOJ4s5iBBnixImrJb4A!2e0!7i13312!8i6656.

Great Streets Studio. (2017). LA Great Streets. Available at: http://lagreatstreets.org.

Huang, H.F., Cynecki, M.J. (2001). The effects of traffic calming measures on pedestrian and motorist behavior. Available at: https://nacto.org/wpcontent/uploads/2015/04/effects_traffic_calming_on_ped_motorist_behavior_huang.pdf.

Human Impact Partners. (2018). Advancing Health Equity in Local Health Departments. Available at: https://humanimpact.org/hipprojects/hegwebinars2017.

Hwang, L-D., Hurvitz, P.M., \& Duncan, G.E. (2016). Cross sectional association between spatially measured walking bouts and neighborhood walkability. International Journal of Environmental Research and Public Health, 13(4), 412.

Jackson, R.J. (2003). The impact of the built environment on health: An emerging field. American Journal of Public Health, 93(9), 1382-1384.

Jacobsen, P.L., Racioppi, F., \& Rutter, H. (2010). Who owns the roads? How motorised traffic discourages walking and cycling. Injury Prevention, 15, 369-373.

King, M.R. (1999). Calming New York City intersections. Available at: http://onlinepubs.trb.org/onlinepubs/circulars/ec019/Ec019_i3.pdf.

Los Angeles County Department of Public Health, Center for Health Impact Evaluation. (2019). Health Impact Assessments. Available at: http://www.publichealth.lacounty.gov/chie/HIA.htm.

Los Angeles County Department of Public Health. (2015). PLACE Overview of Assistance by City. Available at: http://www.publichealth.lacounty.gov/place/PLACE_Overview_of_Assistance_by_City.htm.

Los Angeles Department of Transportation. (2017). High Injury Network. Available at: http://geohub.lacity.org/datasets/4ba1b8fa8d8946348b29261045298a88_0?geometry=118.759\%2C33.984\%2C-117.891\%2C34.155.

Los Angeles Department of Transportation. (2014). People St project evaluation manual. Available at: http://peoplest.lacity.org/wpcontent/uploads/2014/11/People_St_Project_Evaluation_Manual_v1.1.pdf.

McCormack, G.R., \& Shiell, A. (2011). In search of causality: a systematic review of the relationship between the built environment and physical activity among adults. International Journal of Behavioral Nutrition and Physical Activity, 8(125), 1-11.

Mead, J., Zegeer, C., \& Bushell, M. (2014). Evaluation of pedestrian-related roadway measures: A summary of available research. Available at: http://www.pedbikeinfo.org/cms/downloads/PedestrianLitReview_April2014.pdf.

Minnesota Department of Health, Health Partnerships Division. (2016). What can I do to advance health equity? Available at: https://www.health.state.mn.us/communities/practice/resources/publications/docs/1609_healtheq uitylens-conf.pdf.

National Association of City Transportation Officials. (2017). Curb extensions. Available at: https://nacto.org/publication/urban-street-design-guide/street-design-elements/curb-extensions.

Neckerman, K.M., Lovasi, G.S., Davies, S., Purciel, M., Quinn, J., Feder, E., Raghunath, N., Wasserman, B., \& Rundle, A. (2009). Disparities in urban neighborhood conditions: Evidence from GIS measures and field observation in New York City. Journal of Public Health Policy, 30, S264S285.

Nielson, C., McClain, R., \& Hennessey, P.E. (2015). Engineering interim design and tactical urbanism: From cost-effective, quick improvements to powerful public outreach tools. Available at: http://www.fehrandpeers.com/wp-content/uploads/2017/02/ITE-J-article.pdf. 
Painter, K. (1996). The influence of street lighting improvements on crime, fear and pedestrian street use, after dark. Landscape and Urban Planning, 35(2-3), 193-201.

Pliakas, T., Hawkesworth, S., Silverwood, R.J., Nanchahal, K., Grundy, C., Armstrong, B., Casas, J.P., Morris, R.W., Wilkinson, P., \& Lock, K. (2017). Optimising measurement of health-related characteristics of the built environment: Comparing data collected by foot-based street audits, virtual street audits and routine secondary sources. Health \& Place, 43, 75-84.

Public Health Alliance of Southern California. (2019). California Healthy Places Index. Available at: https://healthyplacesindex.org.

Rudolph, L., Caplan, J., Ben-Moshe, K., \& Dillon, L. (2013). Health in All Policies: A Guide for State and Local Governments. Washington, DC and Oakland, CA: American Public Health Association and Public Health Institute. Available at: http://www.phi.org/resources/?resource=hiapguide.

Saelens, B.E., \& Handy, S.L. (2010). Built environment correlates of walking: a review. Medicine and Science in Sports and Exercise, 40(7 Suppl), S550-S566.

Sallis, J.F., Cain, K.L., Conway, T.L., Gavand, K.A., Millstein, R.A., Geremia, C.M., Frank, L.D., Saelens, B.E., Glanz, K., \& King, A.C. (2015). Is your neighborhood designed to support physical activity? A brief streetscape audit tool. Preventing Chronic Disease, 12, E141.

San Francisco Municipal Transportation Agency. (2015). Minna-Natoma Home Zone final evaluation report. Available at: https://www.sfmta.com/sites/default/files/projects/2015/MinnaNatoma\%20Home\%20Zone\%20Final\%20Report\%20TA\%20logo.pdf.

Shay, E., Spoon, S.S., \& Khattak, A.J. (2003). Walkable environments and walking activity. University of North Carolina and Chapel Hill. Available at: http://citeseerx.ist.psu.edu/viewdoc/download?doi=10.1.1.683.5248\&rep=rep1\&type=pdf.

Southern California Association of Governments and Metro. (2013). Conducting bicycle and pedestrian counts: A manual for jurisdictions in Los Angeles County and beyond. Available at: https://media.metro.net/riding_metro/bikes/bikecounttrainingmanual_2.pdf.

The Plan for a Healthy Los Angeles. (2015). The Plan for a Healthy Los Angeles. Available at: http://healthyplan.la/the-plan.

UCLA Center for Health Policy Research. (2014). AskCHIS Neighborhood Edition. Available at: http://askchisne.ucla.edu.

UCLA Sustainable Technology \& Policy Program. (2016). Pedestrian Environmental Quality Index. Available at: http://www.peqiwalkability.appspot.com/about.jsp.

Vision Zero. (2017). What is Vision Zero? Available at: http://visionzero.lacity.org/what-is-vision-zerola.

Xu, Y., \& Wang, F. (2015). Built environment and obesity by urbanicity in the U.S. Health \& Place, 34, 19-29.

Zandieh, R., Martinez, J., Flacke, J., Jones, P., \& van Maarseveen, M. (2016). Older adults’ outdoor walking: Inequalities in neighbourhood safety, pedestrian infrastructure and aesthetics. International Journal of Environmental Research and Public Health, 13(12), 1179.

Author Information

Gabrielle Green, MPP

Division of Chronic Disease and Injury Prevention

Los Angeles County Department of Public Health

3530 Wilshire Blvd, $8^{\text {th }}$ Floor

Los Angeles, California, United States, 90010

ggreen@ph.lacounty.gov

Tel: (213) 351-7846 